\title{
Polyketides from the Marine Sponge Plakortis angulospiculatus
}

\author{
Rosângela de A. Epifanio*, Leandro S. Pinheiro and Natalia C. Alves \\ Departamento de Química Orgânica, Instituto de Química, Universidade Federal Fluminense, Centro, \\ 24020-005 Niterói - RJ, Brazil
}

\begin{abstract}
Este trabalho relata o estudo da composição química da esponja Plakortis angulospiculatus coletada em Fernando de Noronha e Tamandaré, Pernambuco, Brazil. O isolamento dos metabólitos foi guiado através de bioautografia com bactérias marinhas oportunistas e ensaios de toxicidade com Artemia salina, fornecendo o éster metílico furanilidênico já conhecido $\mathbf{1}$ e as substâncias inéditas 2 e 3. As estruturas foram elucidadas por métodos espectroscópicos e através da redução seletiva da ligação dupla 9,10 de $\mathbf{3}$ para obtenção de $\mathbf{2}$.
\end{abstract}

Organic extracts of the marine sponge Plakortis angulospiculatus were studied from two different collections from Pernambuco State, Brazil. Bioautography with opportunistic marine pathogens, with results from the brine shrimp lethality assay, were used to guide the purification of the known furanylidenic methyl ester $\mathbf{1}$ and two new derivatives $\mathbf{2}$ and $\mathbf{3}$. The structures were elucidated by spectroscopic methods and by selective reduction of $\mathbf{3}$ into $\mathbf{2}$.

Keywords: Plakortis angulospiculatus, brine shrimp assay, antibacterial, polyketide

\section{Introduction}

Since the Cambrian, sponges have been abundant and ecologically important members of many marine communities, from polar seas to temperate and tropical waters. They are efficient filter feeders, which provide shelter for invertebrates and fishes, harbor symbionts, compete with other sessile animals for space, and can cause bioerosion on coral reefs. ${ }^{1}$

Sponges of the class Demospongiae are known to produce the largest number and diversity of secondary metabolites isolated from marine invertebrates, most of them with medical relevant biological activities and important ecological roles..$^{2-4}$

Apart from a few alkaloid examples, sponges of the genus Plakortis (order Homosclerophorida, family Plakinidae) contain metabolites with important pharmacological properties, derived from the polyketide pathway. Examples are cyclic peroxides that activate cardiac SR $\mathrm{Ca}^{+2}$ pumping ATPase, with antiproliferative effects on the promastigotes of Leishmania mexicana, and cytotoxic and antifungal activities. ${ }^{2}$

During one of our collection expeditions in Brazil, Plakortis angulospiculatus Schultze was recorded for the

* e-mail: rosangela@rmn.uff.br first time in the Northeastern Brazilian coast (National Marine Parks of Tamandaré and Fernando de Noronha Archipelago, Pernambuco State, BR). ${ }^{5}$ In order to investigate the chemical and bioactivity variance among collections of $P$. angulospiculatus from Tamandaré and Fernando de Noronha, we undertook the isolation and quantification of three furanylidenic methyl esters, two of them new compounds, guided by both brine shrimp assay and bioautography with marine pathogenic bacteria. The results of this study are reported here.

\section{Results and Discussion}

Crude extracts of the collected specimens of $P$. angulospiculatus were screened for their antibacterial activity against two strains of Gram-negative bacteria (Leucothrix mucor and Vibrio parahaemolyticus) and one Gram-positive bacterium (Aerococcus viridans), all known to cause disease in marine invertebrates. ${ }^{6}$

The only sensitive bacterium was Leucothrix mucor, which was inhibited by Tamandaré (TAMA) sponge crude extract. The sample collected in Fernando de Noronha (FN) did not show relevant antibacterial activity.

Different results were also obtained in the brine shrimp lethality assay. The crude extract of $P$. angulospiculatus collected at Tamandaré was more toxic than the sample 
collected in Fernando de Noronha $\left(\mathrm{LC}_{50}=66.1 \mu \mathrm{g} \mathrm{mL}-1\right.$ and $174.2 \mu \mathrm{g} \mathrm{mL}^{-1}$, respectively).

When analyzed by bioautography, the extract of the sponge collected in TAMA showed a significant inhibition zone in the less polar area of the TLC plate. Although thinlayer chromatography and bioautography analyses of the crude extracts revealed a difference in the composition of less polar compounds (those that inhibit the growth of the marine bacterium Leucothrix mucor) further HPLC quantitative analysis revealed that the same metabolites were present in both the TAMA and FN samples, but in different concentrations. Both crude extracts were submitted to vacuum silica gel chromatography in order to obtain two fractions from different polarities from each extract. The antibacterial and toxic (less polar) fractions were separately purified, by normal phase HPLC affording compounds $\mathbf{1}, \mathbf{2}$ and $\mathbf{3}$.

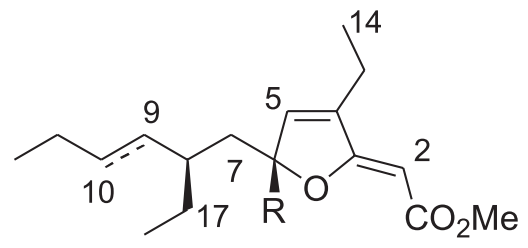

$$
\begin{aligned}
& 1 \mathrm{R}=\mathrm{Et} \\
& 2 \mathrm{R}=\mathrm{Me} \\
& 3 \mathrm{R}=\mathrm{Me} ; \Delta^{9,10}
\end{aligned}
$$

Compound 1 (1.99\% of dry wt TAMA collection) was isolated as a colorless oil, $[\alpha]_{\mathrm{D}}=-167.0(\mathrm{MeOH}, c 0.01)$, which analyzed for the molecular formula $\mathrm{C}_{19} \mathrm{H}_{32} \mathrm{O}_{3}$ by HRFABMS ([MH] $]^{+} \mathrm{m} / z$ found 309.2466 , calc. 309.2431) in combination with NMR methods. The ${ }^{13} \mathrm{C}$ and DEPT NMR spectra for 1 revealed the presence of five methyl groups, seven methylene carbons, three methines and four quaternary carbons. Infrared absorption at 1715 and 1689 $\mathrm{cm}^{-1}$ were observed, which are appropriate for an unsaturated ester. These data suggested that the molecule was of fatty acid origin as those previously isolated from Plakortis spp. Analysis of extensive NMR data, involving ${ }^{1} \mathrm{H}-{ }^{1} \mathrm{H} \operatorname{COSY},{ }^{1} J_{\mathrm{CH}}$ and ${ }^{2,3} J_{\mathrm{CH}}$ HETCOR experiments, allowed complete structural assignments to be made. A literature survey revealed that compound $\mathbf{1}$ had been previously isolated from a Palauan sponge, Plakortis angulospiculatus. ${ }^{7}$ With the exception of the assignments of CH-8 $\left(\delta_{\mathrm{C}} 34.2 ; \delta_{\mathrm{H}} 1.13, \mathrm{~m}\right)$ and $\mathrm{CH}_{2}-17\left(\delta_{\mathrm{C}} 26.9 ; \delta_{\mathrm{H}}\right.$ $1.26, \mathrm{~m})$, and the long-range couplings observed between $\mathrm{H}-2$ and $\mathrm{H}-5(\mathrm{~J} 0.6 \mathrm{~Hz})$ and between $\mathrm{H}-5$ and $\mathrm{H}-13(\mathrm{~J} 1.8$ $\mathrm{Hz}$ ), all the carbon and hydrogen NMR spectral data obtained are identical to those described by Compagnone et al. ${ }^{7}$ Based on the optical rotation in $\mathrm{CHCl}_{3}$ of the isolated compound $\left([\alpha]_{\mathrm{D}}=-77.8, c=0.01\right)$ the absolute stereochemistry of $\mathbf{1}$ was deduced to be $(6 R, 8 S)$, the same as that of the compound described earlier. ${ }^{7}$

Compound 2 ( $1.57 \%$ of dry wt. TAMA collection) was isolated as a colorless oil, $[\alpha]_{\mathrm{D}}=-182.6$ and $-86.6(c$ $0.01, \mathrm{MeOH}$ and $\mathrm{CHCl}_{3}$, respectively). The molecular formula $\mathrm{C}_{18} \mathrm{H}_{30} \mathrm{O}_{3}$, as derived from both HRFABMS ([MH ${ }^{+}$ $\mathrm{m} / \mathrm{z}$ found 295.2259, calc. 295.2274) and combined ${ }^{1} \mathrm{H}$ and ${ }^{13} \mathrm{C}$ NMR data, indicated that $\mathbf{2}$ is a homologue of $\mathbf{1}$ with one less methylene group. The isolated compound, despite having the same molecular formula as a known 6-ethyl,8-methyl derivative, was clearly different as deduced from its NMR spectral data. ${ }^{7} \mathrm{H}$ and ${ }^{13} \mathrm{C}$ NMR spectra of $\mathbf{2}$ contained signals that were nearly identical to the corresponding signals for almost all carbons and

\begin{tabular}{|c|c|c|c|c|}
\hline \multirow[b]{2}{*}{$\mathrm{C} / \mathrm{H}$} & \multicolumn{2}{|c|}{2} & \multicolumn{2}{|c|}{3} \\
\hline & $\delta{ }^{13} \mathrm{C}(\mathrm{DEPT})$ & $\delta^{1} \mathrm{H}(\mathrm{nH}, \mathrm{m}, J$ in $\mathrm{Hz})$ & $\delta{ }^{13} \mathrm{C}(\mathrm{DEPT})$ & $\delta^{1} \mathrm{H}(\mathrm{nH}, \mathrm{m}, J$ in $\mathrm{Hz})$ \\
\hline 1 & $166.8(\mathrm{C})$ & & $166.9(\mathrm{C})$ & \\
\hline 2 & $83.9(\mathrm{CH})$ & $4.83(1 \mathrm{H}, \mathrm{d}, 0.6)$ & $83.8(\mathrm{CH})$ & $4.82(1 \mathrm{H}, \mathrm{d}, 0.9)$ \\
\hline 3 & $171.1(\mathrm{C})$ & & $171.5(\mathrm{C})$ & \\
\hline 4 & $138.6(\mathrm{C})$ & & $138.1(\mathrm{C})$ & \\
\hline 5 & $141.2(\mathrm{CH})$ & $6.28(1 \mathrm{H}, \mathrm{dt}, 1.8,0.6)$ & $141.6(\mathrm{CH})$ & $6.25(1 \mathrm{H}, \mathrm{dt}, 1.8,0.9)$ \\
\hline 6 & $95.1(\mathrm{C})$ & & $5.0(\mathrm{C})$ & \\
\hline $7 \mathrm{a}$ & $42.9\left(\mathrm{CH}_{2}\right)$ & $1.61(1 \mathrm{H}, \mathrm{dd}, 14.5,5.1)$ & $44.9\left(\mathrm{CH}_{2}\right)$ & $1.76(1 \mathrm{H}, \mathrm{m})$ \\
\hline $7 b$ & & $1.80(1 \mathrm{H}, \mathrm{dd}, 14.5,5.2)$ & & $1.94(1 \mathrm{H}, \mathrm{m})$ \\
\hline 8 & $34.6(\mathrm{CH})$ & $1.17(1 \mathrm{H}, \mathrm{m})$ & $40.0(\mathrm{CH})$ & $1.78(1 \mathrm{H}, \mathrm{m})$ \\
\hline 9 & $34.0\left(\mathrm{CH}_{2}\right)$ & $1.20(2 \mathrm{H}, \mathrm{m})$ & $133.7(\mathrm{CH})$ & $5.04(1 \mathrm{H}, \mathrm{ddt}, 15.3,8.7,1.8)$ \\
\hline 10 & $28.8\left(\mathrm{CH}_{2}\right)$ & $1.18(2 \mathrm{H}, \mathrm{m})$ & $132.1(\mathrm{CH})$ & $5.26(1 \mathrm{H}, \mathrm{dt}, 15.3,6.3)$ \\
\hline 11 & $22.8\left(\mathrm{CH}_{2}^{2}\right)$ & $1.24(2 \mathrm{H}, \mathrm{m})$ & $25.5\left(\mathrm{CH}_{2}\right)$ & $1.98(2 \mathrm{H}, \mathrm{m})$ \\
\hline 12 & $14.0\left(\mathrm{CH}_{3}\right)$ & $0.87(3 \mathrm{H}, \mathrm{t}, 6.8)$ & $13.9\left(\mathrm{CH}_{3}\right)$ & $0.95(3 \mathrm{H}, \mathrm{t}, 7.4)$ \\
\hline 13 & $18.3\left(\mathrm{CH}_{2}\right)$ & $2.18(2 \mathrm{H}, \mathrm{dq}, 7.5,1.8)$ & $18.4\left(\mathrm{CH}_{2}\right)$ & $2.12(2 \mathrm{H}, \mathrm{dq}, 7.5,1.8)$ \\
\hline 14 & $11.7\left(\mathrm{CH}_{3}\right)$ & $1.16(3 \mathrm{H}, \mathrm{t}, 7.5)$ & $11.6\left(\mathrm{CH}_{3}\right)$ & $1.14(3 \mathrm{H}, \mathrm{t}, 7.4)$ \\
\hline 15 & $25.4\left(\mathrm{CH}_{3}\right)$ & $1.44(3 \mathrm{H}, \mathrm{s})$ & $26.3\left(\mathrm{CH}_{3}\right)$ & $1.42(3 \mathrm{H}, \mathrm{s})$ \\
\hline 17 & $26.8\left(\mathrm{CH}_{2}\right)$ & $1.30(2 \mathrm{H}, \mathrm{m})$ & $29.3\left(\mathrm{CH}_{2}\right)$ & $1.16(1 \mathrm{H}, \mathrm{m}) ; 1.36(1 \mathrm{H}, \mathrm{m})$ \\
\hline 18 & $10.4\left(\mathrm{CH}_{3}\right)$ & $0.81(3 \mathrm{H}, \mathrm{t}, 7.4)$ & $11.3\left(\mathrm{CH}_{3}\right)$ & $0.77(3 \mathrm{H}, \mathrm{t}, 7.4)$ \\
\hline $\mathrm{O}_{\mathrm{CH}_{3}}$ & $50.4\left(\mathrm{CH}_{3}\right)$ & $3.69(3 \mathrm{H}, \mathrm{s})$ & $50.5\left(\mathrm{CH}_{3}\right)$ & $3.64(3 \mathrm{H}, \mathrm{s})$ \\
\hline
\end{tabular}
hydrogens in $\mathbf{1}$ (Table 1). In comparison with $\mathbf{1}$, the

Table 1. NMR (300MHz, $\left.\mathrm{CDCl}_{3}\right)$ data of $\mathbf{2}$ and $\mathbf{3}^{a}$

${ }^{\text {a } 1} \mathrm{H}$ and ${ }^{13} \mathrm{C}$ assignments made on basis of ${ }^{1} \mathrm{H}-{ }^{1} \mathrm{H}$ COSY and HETCOR $\left({ }^{1} J_{\mathrm{CH}}\right.$ and $\left.{ }^{2,3} J_{\mathrm{CH}}\right)$ experiments. 
exceptions were $\delta_{\mathrm{C}}$ for C- $6 \mathrm{ca} .3 \mathrm{ppm}$ shielded and the presence of a methyl group at $\delta_{\mathrm{C}} 25.4$ and $\delta_{\mathrm{H}} 1.44$ (s) instead of the C-15/C-16 ethyl group. All the ${ }^{1} \mathrm{H}$ NMR resonances of 2 were assigned to their corresponding carbon partner signal by direct $2 \mathrm{D}{ }^{1} \mathrm{H}-{ }^{13} \mathrm{C}$ spectra $\left({ }^{1} J_{\mathrm{CH}}\right)$ analysis (Table 1). Homonuclear ${ }^{1} \mathrm{H}$ COSY and long-range ${ }^{1} \mathrm{H}-{ }^{13} \mathrm{C} 2 \mathrm{D}$ spectra allowed the complete planar structure of 2 to be assigned.

Purification of the less polar fraction obtained from Fernando de Noronha collection yielded compound $\mathbf{3}$ $\left(0.83 \%\right.$ of dry wt FN collection) as a colorless oil, $[\alpha]_{\mathrm{D}}=$ -440.8 and -205.4 ( $c 0.01, \mathrm{MeOH}$ and $\mathrm{CHCl}_{3}$, respectively). The spectral properties of $\mathbf{3}$ were very similar to those of the polyketide 2, except for the presence of the $\mathrm{C} 9,10$ $E$-double bond $\left[\delta_{\mathrm{C}} 133.7\right.$ and $133.1 ; \delta_{\mathrm{H}} 5.04$ (ddt, $J 15.3$, 8.7 and $1.8 \mathrm{~Hz}$ ) and $5.26(\mathrm{dt}, J 15.3$ and $6.3 \mathrm{~Hz})]$. Accordingly, the EIMS spectrum showed a molecular ion at $\mathrm{m} / z 292\left(\mathrm{C}_{18} \mathrm{H}_{28} \mathrm{O}_{3}\right)$ and a base peak at $\mathrm{m} / \mathrm{z} 181$, corresponding to the fragment derived from a $\mathrm{C} 6-\mathrm{C} 7$ cleavage with loss of the side chain. 2D NMR experiments $\left({ }^{1} \mathrm{H}-{ }^{1} \mathrm{H}\right.$ COSY, ${ }^{1} J_{\mathrm{CH}}$ and ${ }^{2,3} J_{\mathrm{CH}}$ HETCOR) confirmed the similarity between $\mathbf{2}$ and $\mathbf{3}$ and confirmed the C9,10 $E$-double bond. The ${ }^{1} \mathrm{H}-{ }^{1} \mathrm{H}$ COSY spectrum indicated that the $\mathrm{H}-9$ olefinic proton $\left(\delta_{\mathrm{H}} 5.04\right.$, ddt, $J 15.3,8.7$ and $\left.1.8 \mathrm{~Hz}\right)$ was coupled to $\mathrm{H}-10\left(\delta_{\mathrm{H}} 5.26\right.$, dt, $J 15.3$ and $\left.6.3 \mathrm{~Hz}\right)$ and $\mathrm{H}-$ $8\left(\delta_{\mathrm{H}} 1.78, \mathrm{~m}\right)$, which in turn is coupled to the nonequivalent methylene protons $\mathrm{Hs}-17\left(\delta_{\mathrm{H}} 1.16, \mathrm{~m}\right.$ and $\left.1.36, \mathrm{~m}\right)$ and $\mathrm{H}-7 \mathrm{~b}$ $\left(\delta_{\mathrm{H}} 1.94, \mathrm{~m}\right)$. It was also possible to observe the couplings between H-10 with Hs-11 $\left(\delta_{\mathrm{H}} 1.98, \mathrm{~m}\right)$ and Hs-11 with a methyl at $\delta_{\mathrm{H}} 0.95(\mathrm{t}, J 7.4 \mathrm{~Hz}$ ) (Table 1).

Subsequent proof of the structures of the new furanylidenic methyl ester, was obtained by reduction of 9,10-double bond of $\mathbf{3}$ with diimide. ${ }^{7}$ The ${ }^{1} \mathrm{H}$ and ${ }^{13} \mathrm{C}$ NMR spectral data, as well as the sodium $\mathrm{D}$ line optical rotation of the obtained product, were identical to those of $\mathbf{2}$.

Based on the same sign and magnitude of optical rotations in $\mathrm{CHCl}_{3}$ of $\mathbf{2}$ and $\mathbf{3}$, when compared with $\mathbf{1}$ and literature data, we assumed that all compounds isolated have the same absolute stereochemistry, $(6 R, 8 S)$ for compound $\mathbf{2}$ and $(6 R, 8 R)$ for compound $\mathbf{3}$.

Although the members of the sponge genus Plakortis are characterized by the production of oxidated fatty acids, the majority of these compounds are cycloperoxides with a few examples of furanylidenic esters derivatives such as $\mathbf{1 - 3} .^{7.8}$

None of the pure polyketide-derived compounds isolated from Plakortis spp. have been assayed for their ecological roles, but indications of their significance have been obtained. Crude extracts of different Plakortis species proved to be unpalatable to reef fish, to inhibit macrofouler settlement or microbial infections. ${ }^{1,4,9}$ It was also demonstrated that Caribbean sponge species yielding antibacterial extracts also deterred feeding by reef fishes, suggesting that some of secondary metabolites may have evolved multiple defensive functions. ${ }^{10}$ The new polyketides $\mathbf{2}$ and $\mathbf{3}$ also exhibited significantly activity in brine shrimp assay with $\mathrm{LC}_{50}$ values of $63.3 \mu \mathrm{g} \mathrm{mL}^{-1}$ and $91.9 \mu \mathrm{g} \mathrm{mL}^{-1}$, respectively.

During our work we demonstrated by bioautography that only the mixture of less polar compounds from the $P$. angulospiculatus sample collected at Tamandaré were active against the marine bacterium Leuchotrix mисоr. Quantitative analysis by HPLC of the crude extracts from both collections showed a different relative concentration of furanylidenic methyl esters in the two samples collected. The results obtained indicated that the mixture of the isolated furanylidenic methyl esters is responsible for the antimicrobial activity observed in disc-diffusion and bioautography antimicrobial assays.

\section{Experimental}

\section{General experimental procedures}

Optical rotations of isolated compounds were measured on a Perkin-Elmer 243B polarimeter $\left(D_{25}=\right.$ $589 \mathrm{~nm}$ ). IR spectra were recorded on a Perkin-Elmer model 1600 (FTIR) spectrometer. Mass measurements were registered on a HP 5989A spectrometer. NMR spectra were recorded in $\mathrm{CDCl}_{3}$ solution on Varian Unit300 spectrometer. Normal phase semi-preparative HPLC were carried out on silica gel columns using Waters model 510 pump, R401 differential refractometer and a 910 photodiode array (200-600 nm) detectors. Isolation procedures were monitored by employing thin-layer chromatography (TLC) on pre-coated silica gel plates.

\section{Sponge collection}

Two different samples of Plakortis angulospiculatus (Plakinidae, Homoscleromorpha, Demospongiae) were collected by SCUBA at a depth of 6-15 m, in March 1996. Sample A (TAMA) was collected off the coast of Tamandaré $\left(08^{\circ} 45^{\prime} \mathrm{S}, 35^{\circ} 06^{\prime} \mathrm{W}\right)$, and B (FN) at Fernando de Noronha $\left(03^{\circ} 51^{\prime} \mathrm{S}, 32^{\circ} 25^{\prime} \mathrm{W}\right)$, both marine protected areas in Pernambuco State, NE Brazil. Samples A and B were frozen immediately after collection and identified by standard methods. Voucher specimens were deposited at the sponge collection of the Departamento de Zoologia, Universidade Federal do Rio de Janeiro [UFRJPOR 3900 (FN) and UFRJPOR 4032(TAMA)]. ${ }^{4}$ 


\section{Extraction and isolation}

Samples A and B of $P$. angulospiculatus were submitted to the same extraction and purification procedures. Frozen sponges were cut into small pieces and extracted with a mixture of $\mathrm{MeOH}: \mathrm{CH}_{2} \mathrm{Cl}_{2}$ (1:1, twice) and pure $\mathrm{CH}_{2} \mathrm{Cl}_{2}$ (once). The extracts were combined and evaporated under reduced pressure. The resulting gum $(\mathrm{A}=18.7 \%$ of dry wt sponge and $\mathrm{B}=25.8 \%$ of dry wt sponge) was submitted to vacuum chromatography in TLC grade silica gel employing a mixture of EtOAc in $n$-hexane $(1: 1)$ to yield two major fractions with different polarities. Normal phase semi-preparative HPLC purification (Dynamax column, $25 \mathrm{~cm}$ length and $9.4 \mathrm{~mm}$ i.d., $n$-hexane:EtOAc, 9:1, flow rate $2.5 \mathrm{~mL} \mathrm{~min}^{-1}$ ) of the less polar fractions obtained from species A (44\% of the crude extract) and B (33\% of the crude extract) afforded compounds 1, 2 and $\mathbf{3}$.

(2Z,6R,8S) [3,5-Diethyl-5-(2-ethyl-hexyl)-5H-furan-2ylidene]-acetic acid methyl ester $(\mathbf{1})^{6}$

Colorless oil; $[\alpha]_{\mathrm{D}}-167.0\left(\mathrm{MeOH}, c\right.$ 0.01); $[\alpha]_{\mathrm{D}}-77.8$ $\left(\mathrm{CHCl}_{3}, c\right.$ 0.01); IR (KBr) $v_{\max } / \mathrm{cm}^{-1}: 2962,2928,2874$, 2857, 1715, 1689, 1639, 1626, 1461, 1433, 1377, 1273, $1159,1060,1040,976,805 ;{ }^{1} \mathrm{H} \mathrm{NMR}\left(300 \mathrm{MHz}, \mathrm{CDCl}_{3}\right) \delta$ 0.79 (3H, t, J 7.2 Hz, H-16), 0.80 (3H, t, J 7.5 Hz, H-18), 0.87 (3H, t, J 6.6 Hz, H-12), 1.13 (3H, m, H-8, H-9ab), 1.14 (2H, m, H-10ab), 1.17 (3H, t, J 7.5 Hz, H-14), 1.22 (2H, m, H-11ab), 1.26 (2H, m, H-17ab), 1.60 (1H, dd, J 5.0, 14.5 Hz, H-7a), 1.70 (2H, m, H-15ab), 1.80 (1H, m, H-7b), 2.18 $(2 \mathrm{H}, \mathrm{dq}, J 7.4,1.8 \mathrm{~Hz}, \mathrm{H}-13), 3.69\left(3 \mathrm{H}, \mathrm{s}, \mathrm{OC}_{3}\right), 4.81(1 \mathrm{H}$, $\mathrm{d}, J 0.6 \mathrm{~Hz}, \mathrm{H}-2)$ and $6.22(1 \mathrm{H}, \mathrm{dt}, J 1.8,0.6 \mathrm{~Hz}, \mathrm{H}-5) ;{ }^{13} \mathrm{C}$ NMR (75.4 MHz, $\left.\mathrm{CDCl}_{3}\right) \delta 8.0\left(\mathrm{CH}_{3}-16\right), 10.5\left(\mathrm{CH}_{3}-18\right)$, $12.0\left(\mathrm{CH}_{3}-14\right), 14.0\left(\mathrm{CH}_{3}-12\right), 18.5\left(\mathrm{CH}_{2}-13\right), 22.9\left(\mathrm{CH}_{2}-\right.$ 11), $26.9\left(\mathrm{CH}_{2}-17\right), 28.9\left(\mathrm{CH}_{2}-10\right), 31.6\left(\mathrm{CH}_{2}-15\right), 34.1\left(\mathrm{CH}_{2}-\right.$ 9), 34.2 (CH-8), 41.5 ( $\left.\mathrm{CH}_{2}-7\right), 50.4$ ( $\left.\underline{\mathrm{CH}}_{3} \mathrm{O}-\right), 83.5$ (CH-2), 98.0 (C-6), 139.7 (CH-4), 139.9 (C-4), 166.8 (C-1), 171.6 (C-3); EIMS (70 eV) m/z $308\left[\mathrm{M}^{+}\right.$(14), 279 (60), 277 (6), 209 (7), 195 (100), 181 (35); HRFABMS (NBA) $\mathrm{m} / \mathrm{z}$ 309.2466 (calc. for $\mathrm{C}_{19} \mathrm{H}_{33} \mathrm{O}_{3}, 309.2431$ ).

(2Z,6R,8S) [3-Ethyl-5-(2-ethyl-hexyl)-5-methyl-5H-furan2-ylidene]-acetic acid methyl ester (2)

Colorless oil; $[\alpha]_{\mathrm{D}}-182.6\left(\mathrm{MeOH}, c\right.$ 0.01); $[\alpha]_{\mathrm{D}}-86.6$ $\left(\mathrm{CHCl}_{3}, c\right.$ 0.01); IR (KBr) $v_{\max } / \mathrm{cm}^{-1}: 2964,2930,2853$, 2857, 1714, 1688, 1639, 1626, 1461, 1434, 1375, 1276, 1167, 1146, 1044, 971, 805; ${ }^{1} \mathrm{H}$ and ${ }^{13} \mathrm{C}$ NMR data see Table 1; EIMS (70 eV) m/z 294 [M]+ (12), 279 (6), 263 (6), 195 (20), 181 (100); HRFABMS (NBA) m/z 295.2259 (calc. for $\mathrm{C}_{18} \mathrm{H}_{31} \mathrm{O}_{3}, 295.2274$ ).
$(2 Z, 6 R, 8 R, 9 E)$ [3-Ethyl-5-(2-ethyl-hex-3-enyl)-5-methyl5H-furan-2-ylidene]-acetic acid methyl ester (3)

Colorless oil; $[\alpha]_{\mathrm{D}}-440.8(\mathrm{MeOH}, c 0.01) ;[\alpha]_{\mathrm{D}}-205.4$ $\left(\mathrm{CHCl}_{3}, c\right.$ 0.01); IR (KBr) $v_{\max } / \mathrm{cm}^{-1}: 2964,2930,2874$, 2853, 1714, 1639, 1626, 1460, 1434, 1375, 1276, 1167, 1146, 1043, 971, 805; ${ }^{1} \mathrm{H}$ and ${ }^{13} \mathrm{C}$ NMR data see Table 1; EIMS (70 eV) m/z $292\left[\mathrm{M}^{+}\right.$(17), 261 (10), 256 (17), 213 (6), 195 (7), 181 (100), 167 (10), 149 (20), 137 (12), 123 (15), 97 (17), 81 (32), 69 (68).

\section{Reduction of (3) with diimide ${ }^{7}$}

To a refluxing solution of $\mathbf{3}(20 \mathrm{mg}, 0.068 \mathrm{mmol})$ and freshly prepared $p$-toluenesulfonhydrazide $(142 \mathrm{mg})$ in THF: $\mathrm{H}_{2} \mathrm{O}$ (1:1, $\left.14 \mathrm{~mL}\right)$, a solution of sodium acetate (109 $\mathrm{mg})$ in water $(8 \mathrm{~mL})$ was added slowly. The reaction was monitored by TLC and after $1 \mathrm{~h}$ of heating the solution was cooled and concentrated under reduced pressure. After addition of saturated aqueous ammonium chloride the product was extracted with $\mathrm{CH}_{2} \mathrm{Cl}_{2}(4 \times 10 \mathrm{~mL})$ and washed with $2 \mathrm{~mol} \mathrm{~L}^{-1} \mathrm{NaOH}$ solution. After evaporation of the solvent, the residue was purified by preparative silica TLC ( $n$-hexane:EtOAc, 9:1) to afford $11.9 \mathrm{mg}$ of (2) (60\% yield). All of the spectral data obtained, including optical rotation, were identical to those of the natural product (2).

\section{Quantitative analysis by HPLC}

Quantitative analyses by HPLC were performed using a silica gel column (3.9 mm i.d., $150 \mathrm{~mm}$ length), a flow rate of $0.2 \mathrm{~mL} \min ^{-1}$ ( $n$-hexane:EtOAc, 9:1) and a photodiode-array detector operating at $280 \mathrm{~nm}$. A stock solution with known amounts of the three isolated compounds (1, 2 and 3) in 10\% EtOAc in $n$-hexane was prepared. Calibration curves were established based on three data points (three injections each) covering a concentration range from 5.0 to $30.0 \mu \mathrm{g} \mathrm{mL}^{-1}$. Solutions of the crude extracts from both collections $\left(50 \mu \mathrm{g} \mathrm{mL}^{-1}\right)$ were prepared and analyzed, affording the following results:\% of compounds in TAMA crude extracts $=20.50 \%$ of $\mathbf{1}$; $15.5 \%$ of $\mathbf{2}$ and $5.20 \%$ of $\mathbf{3} ; \%$ of compounds in $\mathrm{FN}$ crude extracts: $0.64 \%$ of $\mathbf{1} ; 7.50 \%$ of $\mathbf{2}$ and $20.80 \%$ of $\mathbf{3}$.

\section{Brine shrimp assay}

The brine shrimp (Artemia salina) lethality assay was performed as described, ${ }^{11}$ giving the following $\mathrm{LC}_{50}$ results: TAMA crude extract $=66.1 \mu \mathrm{g} \mathrm{mL}^{-1} ; \mathrm{FN}$ crude extract $=$ $174.2 \mu \mathrm{g} \mathrm{mL}^{-1}$ ); Fraction 1 from TAMA $=130.8 \mu \mathrm{g} \mathrm{mL}^{-1}$; Fraction 1 from $\mathrm{FN}=80.2 \mu \mathrm{g} \mathrm{mL}^{-1}$; Compound $\mathbf{1}=$ not 
active; Compound $\mathbf{2}=63.3 \mu \mathrm{g} \mathrm{mL} L^{-1}$; Compound $\mathbf{3}=$ $91.9 \mu \mathrm{g} \mathrm{mL}^{-1}$.

\section{Antibacterial and bioautography assays}

The microorganisms used included two Gram-negative bacteria Leucothrix mucor (ATCC 25906) and Vibrio parahaemolyticus (ATCC 27969) and one Gram-positive bacterium Aerococcus viridans (ATCC 10400). Standard agar disc-diffusion assays were performed as described using $25 \mu \mathrm{L}$ of Tamandaré and Fernando de Noronha crude extracts $\left(\mathrm{c}=6 \mathrm{mg} \mathrm{mL}^{-1}\right) .6$ The crude extract from the Tamandaré sponge was analyzed by bioautography by applying $25 \mu \mathrm{L}$ of the above solution over TLC Merck silica gel plates $5 \times 8 \mathrm{~cm}$. Two pairs of TLC plates were prepared and eluted in EtOAc:isooctane (1:1) and $\mathrm{CH}_{2} \mathrm{Cl}_{2}: \mathrm{MeOH}$ (9:1), respectively. For each eluent system, the first plate was observed under UV and revealed with $50 \% \mathrm{H}_{2} \mathrm{SO}_{4}$ and heating, and the second one was used in the bioautography analysis. The bioautography was performed by allowing the second TLC plate to lay on the surface of the Leucothrix mисоr inoculated agar medium for $30 \mathrm{~min}$. After $36 \mathrm{~h}$, areas of inhibited microbial growth were observed and compared with compound migration values (Rf) from the developed TLC plates. The Rf observed is related to the isolated compounds 1-3.

\section{Acknowledgments}

This work was conducted by N.C.A and L.S.P. as part of a $\mathrm{CNPq}$ undergraduate research program. The collections were performed during an expedition in Brazil, which was financed by a joint CNPq (R.A.E.) and NSF (W. Fenical, Center of Marine Biomedicine and Biotechnology, UCSD) collaborative research grant. We thank M. Maida (UFPE) and CEPENE for the assistance during our visit to Tamandare village, and IBAMA at the National Marine Park of Fernando de Noronha for the field work permits. We also gratefully acknowledge G. Muricy (UFRJ) for the help during collections and taxonomic identification of the sponges and W. Fenical (UCSD) for the bacterial strains and the facilities to perform the antimicrobial assays. This work was supported by funds from $\mathrm{CNPq}$ (Brazil).

\section{References}

1. Pawlik, J. R.; Chanas, B.; Tooner, R. J.; Fenical, W.; Mar. Ecol. Prog. Ser. 1995, 127, 183 and references therein.

2. Blunt, J. W.; Copp, B. R.; Munro, M. H. G.; Northcote, P. T.; Prinsep, M. R.; Nat. Prod. Rep. 2004, 21, 1 and references therein.

3. Epifanio, R. de A.; Gabriel, R.; Martins, D. L.; Muricy, G.; J. Chem. Ecol. 1999, 25, 2247 and references therein.

4. Burns, E.; Ifrach, I.; Carmeli, S.; Pawlik, J. R.; Ilan, M.; Mar. Ecol. Prog. Ser. 2003, 252, 105 and references therein.

5. Muricy, G.; Moraes, F. C.; Rev. Bras. Oceanogr. 1998, 46, 213; Moraes, F. C.; Muricy, G.; J. Mar. Biol. Assoc. UK 2003, $83,385$.

6. Jensen, P. R.; Harvell, C. D.; Wirtz, K.; Fenical, W.; Mar. Biol. 1996, 125, 411.

7. Compagnone, R. S.; Piña, I. C.; Rangel, H. R.; Dagger, F.; Suarez, A. I.; Reddy, M. V. R.; Faulkner, D. J.; Tetrahedron 1998, 54, 3057.

8. Cafieri, F.; Fattorusso, E.; Taglialatela-Scafati, O.; Tetrahedron 1999, 55, 7045; Stierle, D. B.; Faulkner, J. D.; J. Org. Chem. 1980, 45, 3396; Smith, E. W.; Faulkner, D. J.; Tetrahedron Lett. 1996, 37, 6681.

9. Kelly, S. R.; Jensen, P. R.; Henkel, T. P.; Fenical, W.; Pawlik, J. R.; Aquat. Microb. Ecol. 2003, 31, 175.

10. Newbold, R. W.; Jensen, P. R.; Fenical, W.; Pawlik, J. R.; Aquat. Microb. Ecol. 1999, 19, 279.

11. Meyer, B. N.; Ferrigni, N. R.; Putnam, J. E.; Jacobsen, L. B.; Nichols, D. E.; McLaughlin, J. L.; Planta Med. 1982, 45, 31; Nelson, A. C.; Kursar, A.; Chemoecology 1999, 9, 81.

Received: April 7, 2005 Published on the web: September 15, 2005 